\title{
Fantastyczna metafizyka, czyli rzecz o (nie)możliwościach Biblioteki Zorana Živkovicia
}

\begin{abstract}
Metaphysical Fantastic. The (Im)possibilities in Zoran Zivkovic's Library

The aim of the article was to present the complex problem of a different kind of (im)possibilities in The Library by Zoran Zivkovic, and to reveal the mechanism of changing impossible (on physical and metaphysical basis) into possible by reffering to few philosophical theories and some cultural concepts. Presented paper focuses on interesting ways of showing the different approach to the symbolic meaning of the book and the library, also pointing to universalism of Zivkovic's prose as the most important determinant of his poetics.
\end{abstract}

Keywords: metaphysical fantastic prose, library, idée fixe liber mundi, infinity, (im)possibility.

Słowa kluczowe: metafizyka fantastyki, biblioteka, idée fixe liber mundi, nieskończoność, (nie) możliwość.

Książka - przedmiot pożądania każdego bibliofila - przyciąga swoją złożonością zamkniętą w jakże prostej formie. Ten będący symbolem nauki i atrybutem uczonych (wy)twór kryje w sobie wiele sprzeczności. Jest równocześnie obiektem skończonym i nieskończonym, pełnym i wymagającym uzupełnienia, zaspokajającym ciekawość człowieka i jednocześnie ją rozbudzającym, jednym słowem - fascynującym! Książka, zrodzona z ludzkiej potrzeby utrwalania wiedzy, rozbudziła także kolejną potrzebę - jej gromadzenia, dając początek bibliotece. O jednej i drugiej pisze w powieści mozaice Biblioteka Zoran Živković, czyniąc obie głównymi bohaterkami swojego utworu.

Powstała w 2002 roku Biblioteka to zaledwie sześć nowel i zarazem sześć różnych bibliotek, których wspólnym motywem staje się właśnie książka. Dzięki niej bohaterowie każdego z opowiadań wchodzą w kontakt ze światem literatury, „który jest jednocześnie realny, niezwykły, uwodzicielski, niebezpiecz- 
ny i nierzeczywisty" " Książka i stosunek do niej bohaterów służy autorowi do przedstawienia problemów i zadania uniwersalnych pytań, które od wieków trawią ludzkość i pojedyncze jednostki.

Zbiór otwiera Wirtualna biblioteka (Virtuelna biblioteka), której bohater - pisarz, pośród licznej, niechcianej i zaśmiecającej skrzynkę korespondencji, znajduje pewnego dnia tajemniczy mail. Jego nadawcą jest Wirtualna Biblioteka reklamująca się hasłem: „Mamy wszystko!”. Treść otrzymanego spamu irytuje i jednocześnie prowokuje do kliknięcia w załączony link, a naturalna ciekawość, wzbogacona dozą narcyzmu, każe wpisać w okienko wyszukiwarki własne nazwisko. Rezultat wyszukiwania jest zaskakujący. Na ekranie obok krótkiej noty biograficznej, uwzględniającej aż dziewięć różnych dat śmierci pisarza, pojawia się także kompletna nota bibliograficzna, zawierająca tytuły napisanych i nienapisanych jeszcze książek. Domowa biblioteka (Kućna biblioteka) to z kolei opowieść o człowieku, który w niewyjaśniony sposób zaczyna znajdować w swojej skrzynce na listy tomy literatury światowej i znosząc je do mieszkania, tworzy pokaźnych rozmiarów bibliotekę. Bohater następnego opowiadania, Nocna biblioteka (Noćna biblioteka), zamknięty przez własną nieuwagę w gmachu miejskiej biblioteki po godzinach pracy, odkrywa w jej wnętrzu istnienie innej, budzącej pewien niepokój biblioteki, której półki wypełnione są równie niepokojącymi „księgami życia”. Piekielna biblioteka (Paklena biblioteka) stanowi kolejną literacką wizję piekła, tym razem przyjmującego postać diabelskiego zakładu penitencjarnego - biblioteki, w której grzesznicy poddawani są terapii wiecznego czytania. Najmniejsza biblioteka (Najmanja biblioteka) to historia pisarza, w którego ręce trafia niezwykłe dzieło, zmieniające swoją treść po każdorazowym ponownym jego otwarciu. I wreszcie ostatnie opowiadanie, Wykwintna biblioteka (Otmena biblioteka), w którym łączą się wszystkie wcześniejsze, przedstawia bohatera bibliofila. Nie mogąc pozbyć się niechcianej książki, postanawia on bibliotecznego intruza skonsumować i sporządza z niego wykwintny posiłek. Živković, podobnie jak Italo Calvino w powieści Jeśli zimowa noca podróżny, zaskakuje swoich czytelników na sam koniec, podczas lektury bowiem orientują się, że niepasująca do księgozbioru bohatera książka jest tą, którą właśnie czytają.

Tematem wszystkich sześciu historii jest tak naprawdę istniejąca w rzeczywistości pozaliterackiej niemożliwość, która w świecie Biblioteki staje się możliwa, oraz niezaspokajalne i odwieczne ludzkie pragnienie, które w fantastycznej przestrzeni tekstu Živkovicia można jednak ugasić. W tekście serbskiego autora niemożliwość istnieje $\mathrm{w}$ dwóch różnych wymiarach. Pierwszy z nich odnosi się do niemożliwości czysto fizycznej, która oczywiście zastanawia przez chwilę czytelników (konfrontujących tekst z rzeczywistością), ale jest przyjmowana raczej ze spokojem przez samych bohaterów. Nie jest przecież możliwe, by istniała wirtualna biblioteka posiadająca w swoich zbiorach wszystko, co kiedykolwiek i przez kogokolwiek zostało napisane i ten, kto to wymyślił „z pewnością nie ma bladego pojęcia, ile książek powstało w ciągu ostatnich pięciu tysięcy lat.

„koji je istovremeno realan, čudesan, primamljiv, opasan i nestvaran”, N. Polovina, Kratka priča u stvaralačkom konceptu Zorana Živkovića, „Sveske” 2005, nr 78, s. 67. Wszystkie thumaczenia, jeśli nie podano inaczej, pochodzą od autorki artykułu. 
Nikomu nigdy nie udało się zebrać w jednym miejscu takiej biblioteki, nawet bez tych dzieł, które w ogóle się nie zachowały"2. Nie jest możliwe także, by książki samoistnie pojawiały się w skrzynce pocztowej, cudownie się w niej materializując po każdorazowym jej opróżnieniu, a jednak bohatera „nic nie dziwiło [...]. Świat jest pełen dziwów, których nie można objaśnić. [...] Niezwykłe rzeczy po prostu trzeba przyjąć jako takie, bez wyjaśniania" " ${ }^{3}$. Niemożliwe jest również, by jedna i ta sama książka przedstawiała zupełnie nową treść po każdym ponownym jej otwarciu, bowiem, ,żadna książka nie może tak po prostu zmienić tytułu sama z siebie. To każdy wie. Ale to się właśnie stało" 4 .

Niemożliwość fizycznego zaistnienia pewnych sytuacji w rzeczywistości pozaliterackiej zostaje $\mathrm{w}$ tekście przezwyciężona, na co pozwala przyjęta przez autora konwencja fantastyczna utworu. Niewiarygodne okoliczności, w jakich dochodzi do spotkania bohatera z książką i jednocześnie z literaturą, tracą zatem swoją niewiarygodność i stają się całkiem możliwe. „Wydaje się, że pod koniec każdej opowieści niepewność znika. Skonfrontowany z momentem fantastycznym bohater Živkovicia żyje dalej, mając nowe, niepowtarzalne doświadczenie"s.

W Bibliotece obecny jest także drugi rodzaj niemożliwości - tej na poziomie metafizycznym. W odróżnieniu od niemożliwości fizycznej, niemożliwość metafizyczna rodzi się z pragnień ludzkich, by osiągnąć coś, co ze swej natury jest nieosiągalne. I w tym przypadku Živković przekształca realną niemożliwość w literacką możliwość. Przykład znaleźć można już w pierwszym opowiadaniu Biblioteki, w którym mowa jest o niemożliwości realizacji wszystkiego, co potencjalnie możliwe. Zawierająca spis tych istniejących i tych jeszcze nienapisanych przez pisarza utworów notka bibliograficzna, którą bohater znajduje przy swoim nazwisku w wirtualnej bibliotece, to wariacja na temat filozoficznej koncepcji potencji. Arystotelesowska teza, że każdy byt składa się z możności (potencji) oraz aktu, a więc materii oraz formy, zakłada, iż nieokreślone tworzywo, jakim jest właśnie materia, może tworzyć jedynie byt potencjalny. Istnienie w potencji to nieskończona ilość możliwych realizacji, a w przypadku bohatera Wirtualnej biblioteki to zbiór wszystkich potencjalnie możliwych utworów literackich, z których jednak tylko część otrzyma formę. Hylemorficzna natura bytów realnych ogranicza fizyczne możliwości bohatera. Napisanie wszystkich pozycji z bibliograficznego spisu staje się niemożliwe z różnych względów, czysto obiektywnych, takich jak np. długość życia, ale i subiektywnych, zależnych od podejmowanych decyzji i dokonywanych przez pisarza wyborów, jednak fantastyczna, wirtualna biblioteka daje bohaterowi przynajmniej możliwość zerknięcia we własną potencję, daje świadomość wielu możliwych scenariuszy życia.

Innym niemożliwym do zaspokojenia pragnieniem człowieka jest to, wyrażone w figurze liber mundi, „księdze świata”, marzenie uczonych, by w jednej księdze zawrzeć całą dostępną wiedzę i mądrość, a tym samym ujarzmić wszech-

2 Z. Živković, Biblioteka, przeł. M. Szklarski et al., Toruń 2008, s. 7.

3 Ibid., s. 22.

4 Ibid., s. 83.

5 „Na kraju svake priče, čini se, neizvesnosti nema. Suočen s jednim fantastičnim trenutkom, Živkovićev junak nastavlja da živi s novim, neponovljivim iskustvom”, N. Polovina, op. cit., s. 67. 
świat i nad nim zapanować. Idea liber mundi, mit absolutnej całości zamkniętej w jednostkowym przedmiocie, powracający motyw pisarstwa Jorge Luisa Borgesa, implikujący potrzebę gromadzenia wiedzy, katalogowania i porządkowania jej, tworzenia archiwów i bibliotek, obecny jest także w Bibliotece Živkovicia. W trzech opowiadaniach z tego tomu: Domowej bibliotece, Nocnej bibliotece oraz Najmniejszej bibliotece w różny sposób realizowana jest ta idea „wszystkiego w jednym", idea miejsca, ,gdzie są, nie mieszając się, wszystkie miejsca świata".

W Domowej bibliotece autor mierzy się z nieskończonością literatury światowej, którą jednak udaje się zmieścić w ograniczonej przestrzeni kilkudziesięciu metrów kwadratowych. Znosząc do mieszkania pojawiające się wciąż w skrzynce pocztowej kolejne tomy literatury światowej, bohater uświadamia sobie, że rozrastająca się w zastraszającym tempie biblioteka dosłownie pożera, niczym schodzący z gór lodowiec, całą dostępną przestrzeń.

Doskonale wiadomo, że książki bezlitośnie pochłaniają przestrzeń. Przed tym nie ma obrony. Ile tylko miejsca człowiek by im dał, nigdy to nie wystarcza. Obsiądą najpierw ściany, a potem dalej się rozprzestrzeniają, gdzie tylko możliwe. Jedynie sufit zostaje oszczędzony. Ciągle przybywają nowe, a człowiek nie ma serca, żeby pozbyć się którejkolwiek ze starych. I tak powolutku, niezauważalnie tomy wypierają wszystko przed sobą. Jak lodowce?

Układane początkowo na podłodze, starannie, z pietyzmem należnym obiektom przynależnym do sfery sacrum, książki zaczynają zapełniać mieszkanie bohatera, pnąc się ku sufitowi w równych rzędach i stosach, zajmując wszystkie ściany, przejścia, parapety i wnęki. Bohater, w imię poświęcenia dla wyższej sprawy (,Nadzwyczajne sytuacje wymagają, by się człowiek trochę pomęczył i poświęcił"8), zmuszony zostaje do pozbycia się z mieszkania najpierw wszystkich zbędnych, a następnie i niezbędnych domowych sprzętów, zaczynając od szaf i szafek, przez stół i krzesła, a na łóżku kończąc. Obserwujemy tu pewien paradoks przestrzeni, która jednocześnie kurczy się (bohaterowi zostaje coraz mniej wolnego miejsca) i rozszerza (coraz więcej książek daje się upchnąć w tym samym ograniczonym wymiarze). W Domowej bibliotece Živkovicia odnajdujemy także Hrabalowskie motywy z powieści Zbyt głośna samotność, gdzie również główny bohater staje się mimowolnym bibliotekarzem z szacunku do książki, literatury, wiedzy.

Co dzień pod wieczór - mówi Haňtio - noszę do domu w teczce książki i moje mieszkanie na Holeszovicach wypełnione jest tylko i jedynie książkami, pełna jest ich piwnica i komórki już nie starczyło, moja kuchnia jest pełna, spiżarka i klozet także, [...] nad klozetową muszlą na wysokości półtora metra są już belki i dyle, a na nich pod sam sufit piętrzą się książki, pięć kwintali książek [...]".

6 J.L. Borges, Alef [w:] idem, Historie prawdziwe i wymyślone, przeł. A. Sobol-Jurczykowski et al., Warszawa 1993, s. 140.

7 Z. Živković, op. cit., s. 28.

8 Ibid., s. 30.

9 B. Hrabal, Zbyt glośna samotność, przeł. P. Godlewski, Izabelin 2003, s. 22. 
Niemożliwość zamknięcia całej powstałej i wciąż w szybkim tempie przyrastającej literatury światowej w jednym miejscu zostaje u Živkovicia przezwyciężona, czego najlepszym dowodem jest właśnie ta fantastyczna domowa biblioteka.

Oksymoronicznie wyrażoną ideę jednoczesnej skończoności i nieskończoności, której symbolem, prócz wspomnianej wyżej biblioteki, jest przede wszystkim sama książka, odnajdujemy także w Najmniejszej bibliotece. Zamknięty w materialnej formie wolumin zawiera przecież relatywnie ograniczoną, mieszczącą się między okładkami treść, stanowi skończony ciąg znaków, akapitów i stron, a jednocześnie, ze względu na swą podatność na intelektualną obróbkę, daje nieskończoną liczbę możliwych interpretacji, tworząc tym samym nieskończoną ilość nowych dzieł. Bohater Najmniejszej biblioteki to pisarz, którego opuściło natchnienie i moc twórcza. W poszukiwaniu inspiracji, a może i dla przewietrzenia umysłu, przemierza ulice miasta, kiedy natrafia na handlarza starych książek, od którego otrzymuje tajemniczy tomik. Okazuje się, że każdorazowo otwierana przez bohatera książka ma zupełnie inny tytuł i treść, a jedynym niezmiennym elementem pozostaje zamieszczony na stronie przedtytułowej napis: „Najmniejsza biblioteka". Niemożliwość ta początkowo budzi strach, jednak już po chwili zaczyna intrygować. „Dziwne - mówi do siebie bohater - jak człowiek łatwiej przyjmuje niemożliwe, kiedy ono przestaje go straszyć"10. Cudowna właściwość niewielkiej książeczki czyni ją w rzeczywistości najmniejszą biblioteką świata, obejmującą w jednym tomie nieskończoną ilość nowych tytułów, niestety - jednokrotnego użytku. Istota książki, wyrażona w jej skończonej nieskończoności, finitum capax infiniti, co należy podkreślić, leży zatem w jej złożoności i - jak zauważa Andrzej Dróżdż - jej istnieniu ,w dwóch dialektycznych warstwach: materialnej, tj. zewnętrznej, posiadającej budowę skończoną, poddającą się rygorom intelektualnym i technologicznym, oraz w warstwie wewnętrznej, którą wypełnia tekst, zawierający ładunek treści określonych i nieokreślonych [...]"11.

Motyw wielości utworów istniejących w obrębie jednego tekstu w Najmniejszej bibliotece można odczytać w kluczu Ingardenowskiej teorii dzieła literackiego. Filozof wskazuje na istnienie w tekstach miejsc niedookreślonych, które czytelnik w procesie lektury konkretyzuje; innymi słowy, pisząc utwór, autor szkicuje zaledwie pewien zarys jego treści, którego uzupełnienie leży po stronie odbiorcy. To uczestnictwo czytelnika w procesie tworzenia dzieła literackiego sprawia, że staje się on jego współautorem.

Konkretyzacja dzieła literackiego [...] - pisze Ingarden - jest wypływem spotkania się dwu różnych czynników: samego dzieła i czytelnika, a w szczególności jego twórczych i odtwórczych czynności, które spełnia podczas lektury. [...] Poszczególne konkretyzacje różnią się znacznie pomiędzy sobą, a także mniej lub więcej od samego dzieła. Jest ich przede wszystkim wiele, w przeciwieństwie do jednego i tego samego dzieła, każda z nich bowiem odpowiada jednemu odczytywaniu dzieła. Jeżeli pewne dzieło czytamy po raz wtóry [...], to poprzednio przez nas utworzone konkretyzacje wpływają, w pewnej mierze przynajmniej, na własności konkretyzacji właśnie tworzonej. Nie jest ona jednak ,przeróbką” dawnych, lecz czymś w stosunku do nich całkiem no-

10 Z. Živković, op. cit., s. 86.

11 A. Dróżdż, Od liber mundi do hipertekstu: książka w świecie utopii, Warszawa 2009, s. 85. 
wym, drugim. Ilu czytelników i ile odczytań tego samego dzieła, tyle nowych tworów intencjonalnych, które nazywamy konkretyzacjami dzieła ${ }^{12}$.

Najmniejsza biblioteka Živkovicia z jednej strony jest opowiadaniem o ludzkim pragnieniu posiadania wszystkiego w jednym, całej literatury ukrytej pod postacią jednej książki; z drugiej zaś jest literacką reprezentacją teorii wyrosłych z założeń Ingardena, wyrazem koncepcji mówiących o nieskończoności możliwych interpretacji dzieła literackiego, które wielokrotnie czytane, za każdym razem mówi o czymś innym i tworzy nową, inną treść.

Ostatnią z trzech bibliotek rozwijającą temat idée fixe, czyli liber mundi, jest Nocna biblioteka, do której bohater i zarazem narrator opowieści trafia przez przypadek. Choć istnieje w tej samej przestrzeni co dzienna, nocna biblioteka funkcjonuje ewidentnie w innym, fantastycznym wymiarze, a jej zbiory ograniczają się tylko do tajemniczych „ksiąg żywota”, będących zapisem życia wszystkich ludzi, którzy kiedykolwiek żyli na tym świecie.

Mamy jedynie księgi życia - zwraca się do bohatera nieco demoniczny, nocny bibliotekarz. - [...] Wyjątkowo ciekawa lektura. Wbrew rozpowszechnionemu uprzedzeniu rzeczywiste żywoty są często bardziej wzruszające od tych, które się wymyśla. [...] Mimo że jest tyle żywotów, każdy z nich jest wyjątkowy i niepowtarzalny. Drogocenny. Dlatego zasługuje na to, żeby został zanotowany. Stąd i księgi żywotów ${ }^{13}$.

Bohater opowiadania, wiedziony zwykłą ciekawością i jednocześnie niedowierzaniem, prosi bibliotekarza o egzemplarz własnej księgi i z zaskoczeniem stwierdza prawdziwość wszystkich opisanych w tomie szczegółów ze swojej przeszłości. Nocna biblioteka jawi się zatem jako jedno wielkie i wiecznie istniejące archiwum ludzkich istnień, przestrzeń niekończących się korytarzy zapełnionych książkami i katalogami, korespondująca literacko zarówno z Biblioteka Babel Borgesa, jeśli chodzi o motyw biblioteki totalnej, obejmującej wszystkie książki, jak i z opowiadaniem Danilo Kiša Encyklopedia umartych, w którym również pojawia się ogromne archiwum zawierające opisy przeszłych istnień ludzkich. Można wręcz przyjąć, że jest to jedno i to samo źródło, jak bowiem stwierdza sam Kiš: „Encyklopedia umarłych wywodzi się niewątpliwie z półek biblioteki znakomitego Argentyńczyka, gdyż, jak on sam powiada, w jego bibliotece znajdują się wszystkie książki świata. Ale «w tej bibliotece nie ma dwóch jednakowych książek»»"14.

Poza obsesją księgi nowelę Živkovicia łączy z utworem Kiša także zagadnienie ludzkiej śmiertelności i przemijania, z którym wiąże się wpisane w świadomość zbiorową pragnienie pozostawienia po sobie jakiegoś materialnego znaku egzystencji, jakiejś formy, która przetrwa i przez to uczyni nas nieśmiertelnymi. Non omnis moriar - zdaje się wpisane w tkankę literacką obu tych utworów.

12 R. Ingarden, Z teorii dzieła literackiego [w:] Teorie literatury XX wieku. Antologia, red. A. Burzyńska, M.P. Markowski, Kraków 2007, s. 61-62 (wyróżnienia pismem rozstrzelonym zgodne z oryginałem).

13 Z. Živković, op. cit., s. 47-48.

14 D. Kiš, Nazywać znaczy tworzyć [w:] idem, Życie, literatura, przeł. D. Cirlić-Straszyńska, Izabelin 1999, s. 109. 
W Nocnej bibliotece Živković bawi się motywem księgi, w której zapisane jest całe nasze życie, i raz jeszcze urzeczywistnia niemożliwe w literaturze.

Zupełnie inne w przekazie jest opowiadanie Wykwintna biblioteka, będące historią pewnego kompulsywnego smakosza literatury, który za wszelką cenę stara się pozbyć książki budzącej w nim odrazę i złość ze względu na jej kieszonkowe wydanie. Niepasująca swoim formatem i wyglądem do reszty pozycji domowej biblioteczki książka nie daje się jednak pozbyć. Nie pomaga wyrzucenie jej do kosza na śmieci, podarcie na strzępy, utopienie z przywiązanym do grzbietu kamieniem, zrzucenie z wieżowca na ruchliwą ulicę czy wreszcie rzucenie pod nadjeżdżający pociąg. Przy każdej próbie zniszczenia tomu w niewytłumaczalny sposób powraca on w nienaruszonym stanie na półkę. Sfrustrowany i doprowadzony do ostateczności bohater postanawia książkowego intruza skonsumować, uznając to za jedyne skuteczne rozwiązanie swojego problemu. Kiedy kładzie niepokorny egzemplarz na stole, spostrzega, że ten składa się z sześciu części, tworzących idealnie skomponowany z przystawki, zupy, dania głównego i deseru z kawą wykwintny posiłek. Każda z odkrojonych części okazuje się jednak rozdziałem książki, którą czytelnik w tej właśnie chwili czyta.

Wirtualna biblioteka bardzo przypominała dobrą sałatkę jarzynową. Zawierała może jedynie trochę więcej majonezu, niż lubię. Domowa biblioteka była niczym gęsty i obfity rosół wołowy z makaronem. Wydawała mi się zbyt gorąca, więc dmuchałem na łyżkę. Nocna biblioteka odpowiadała nadziewanym paprykom. Zawierały mięso i ryż w odpowiednich proporcjach, co w przypadku tego dania jest bardzo ważne. Piekielna biblioteka stanowiła pyszną pitę z wiśniami. Nie jestem akurat wielkim miłośnikiem słodkości, ale to był wyjątek. Najmniejsza biblioteka dostarczała kawę z bitą śmietaną. Bardziej smakowałaby mi nieco łagodniejsza, ale nie trzeba dzielić włosa na czworo ${ }^{15}$.

Po istnej uczcie na talerzu bohatera zostaje już tylko ostatni kawałek Biblioteki - Wykwintna biblioteka, której smak wydawał się bohaterowi znajomy, ,aczkolwiek trudno było powiedzieć, czy jest w przeważającej mierze słony, ostry, kwaśny czy słodki. Jakby był tym wszystkim naraz"16.

W opowiadaniu Živkovicia pojawia się zatem nowy kształt starej już metafory przedstawiającej czytanie jako rodzaj duchowej uczty. Zrównanie obu czynności (czytania i jedzenia), widoczne w utartych zwrotach językowych, takich jak: pochłanianie wiedzy, nietrawienie/przetrawienie jakichś treści, połykanie całych książek, smakowanie literatur, ma swoją genezę w przeszłości i - jak zaznacza Dróżdż - „do utrwalenia wyobrażeń, że treści materialne potrafią przemieszczać się z treściami duchownymi, przyczynił się starotestamentowy nakaz spożywania Księgi, aby jej treści zostały przetrawione bez reszty (Ez 2, 8-9; 3, 1-3), kontynuowany przez św. Jana i umieszczony w Apokalipsie (Ap 10, 8-11)"'17. W przeciwieństwie jednak do biblijnych zaleceń pochłaniania ksiąg w celu lepszego przyswojenia ich wartościowych treści, bohater Wykwintnej biblioteki działa z podłych i egoistycznych pobudek - niemożliwości zniszczenia niechcianej książki i chęci całkowitego nad nią zapanowania, a sam motyw bibliofagii, która w literaturze

15 Z. Živković, op. cit., s. 108-109.

16 Ibid., s. 109.

17 A. Dróżdż, op. cit., s. 59. 
występuje w różnych postaciach, kontekstach i konwencjach, u Živkovicia przybiera kształt aż nadto dosłowny.

Do wielu wariacji na temat książki i biblioteki, jakie można odnaleźć w literaturze i w samej Bibliotece, dorzucić można jeszcze jedną - mękę wiecznego czytania opisaną w Piekielnej bibliotece. Różniące się od pozostałych opowiadanie, mające ironiczny i zarazem komiczny charakter, przedstawia wizję piekła na miarę XXI wieku, w którym osadzonych poddaje się „terapii” wiecznego czytania. Jak wynika ze statystyk oraz ostatnio prowadzonych badań, ludzie popełnialiby mniej przestępstw, gdyby więcej czytali, ponieważ poświęcając swój czas lekturze, nie mieliby go na zbrodnie. Prosta logika tego stwierdzenia leży u podstaw reformy piekielnych czeluści. Jak tłumaczy świeżo przybyłemu do piekła grzesznikowi reformę jeden z jego ,pracowników”:

Sprawa była prosta. Wprowadziliśmy czytanie jako powszechny obowiązek. Tym samym połączyliśmy przyjemne z pożytecznym. Przede wszystkim umożliwiliśmy naszym wychowankom usunięcie głównego braku, który ich tutaj przywiódł. Gdyby więcej czytali, mieliby mniej pobudek i czasu na przestępstwa ${ }^{18}$.

Nieuchronność i wieczność kary oraz zapowiedź okrutnej męki niekończącej się, przymusowej lektury mogą oczywiście wywoływać uśmiech na twarzy miłośnika książek, w sercach zagorzałych bibliofobów może się jednak pojawić prawdziwy lęk.

Mimo że Zoran Živković, jak sam wielokrotnie podkreślał, nie jest twórcą prozy mimetycznej, a jego utwory nie są komentarzem do rzeczywistości, trudno nie zauważyć, ile jest w nich ładunku filozoficznego i uniwersalnych wartości. Znaczna część dorobku serbskiego pisarza - i Biblioteka nie stanowi tu wyjątku - określana jest mianem fantastyki metafizycznej, która w swojej treści stawia pytania natury ontologicznej i epistemologicznej.

Zgadzam się, że większość z tego, co napisałem, można określić mianem „fantastyki metafizycznej” w tym sensie, że dotyka ona kwestii egzystencjalnych - mówi sam autor. I chociaż wydaje się, że pytania egzystencjalne są domeną wyłącznie filozofii, jest to mylne przekonanie. [Zajmują się nimi] także inne dyscypliny nauki i sztuki i one także mają w tym temacie coś do powiedzenia. Wśród dziedzin sztuki proza niewątpliwie wiedzie prym. Można zaryzykować stwierdzenie, że zajmowanie się pytaniami egzystencjalnymi stanowi dla niej największe wyzwanie. [...] Jedynie Sztuka, a ze wszystkich jej gałęzi literatura najgłębiej, przenika w najbardziej dramatyczną tajemnicę ludzkiej egzystencji ${ }^{19}$.

Dla Živkovicia literatura stanowi najlepsze narzędzie służące badaniu ludzkiej natury, dlatego w swojej fantastycznej prozie bawi się tematami filozoficznymi,

18 Z. Živković, op. cit., s. 67-68.

19 "Slažem se da se glavnina onoga što sam napisao može odrediti kao „metafizičke fantazije” u smislu da se bavi takozvanim krajnjim pitanjima. Iako možda izgleda da se krajnja pitanja u isključivoj nadležnosti filozofije, to je ipak samo privid. Druge duhovne discipline i umetnosti i te kako imaju šta da kažu o tim pitanjima. Među umetnostima, proza svakako prednjači u tom pogledu. Moglo bi se čak reći da je bavljenje krajnjim pitanjima njen krajnji izazov. [...] Jedino Umetnost, a od svih umetnosti književnost najdublje ponire u najdramatičniju tajnu ljudskog postojanja”, M. Morison, Razgovor sa Zoranom Živkovićem [w:] Književna fantastika. Almanah, red. D. Igrošanaca, Beograd 2014, s. 208 i 211. 
pisze o codziennej cudowności życia, o przekraczaniu granic niemożliwego, czy o pragnieniu nieśmiertelności. Jego bohaterowie są najczęściej bezimienni, etnicznie i narodowościowo nieokreśleni, a mówiąc o sobie, ,rzucają światło jedynie na tą skrajną, graniczną część własnej egzystencji, która się ujawnia w trakcie opowiadania" ${ }^{20}$. Opisywane sytuacje i zdarzenia mogłyby wydarzyć się wszędzie bez żadnej straty dla spójności i wiarygodności historii. Takie przedstawianie umożliwia autorowi osiągnięcie maksymalnego uniwersalizmu świata przedstawionego, który z kolei pozwala czytelnikowi skupić się na obecnej w tekście warstwie metafizycznej. Konwencja fantastyczna natomiast, jak stwierdza autor, „otwiera całe nowe obszary wyższych rzeczywistości” ${ }^{21}$, w których niemożliwe staje się możliwe.

\section{Bibliografia}

Beskrajno širenje književno kosmosa. Sa Zoranom Živkovićem razgovarala Tamara Jelin, „Sveske” 2005, nr 78.

Borges J.L., Alef [w:] idem, Historie prawdziwe i wymyślone, przeł. A. Sobol-Jurczykowski et al., Warszawa 1993.

Dróżdż A., Od liber mundi do hipertekstu: ksiażka w świecie utopii, Warszawa 2009. Hrabal B., Zbyt głośna samotność, przeł. P. Godlewski, Izabelin 2003.

Ingarden R., Z teorii dzieła literackiego [w:] Teorie literatury XX wieku. Antologia, red. A. Burzyńska, M.P. Markowski, Kraków 2007.

Kiš D., Nazywać znaczy tworzyć [w:] idem, Życie, literatura, przeł. D. Cirlić-Straszyńska, Izabelin 1999.

Morison M., Razgovor sa Zoranom Živkovićem [w:] Književna fantastika. Almanah, red. D. Igrošanac, Beograd 2014.

Pešikan-Ljuštanović Lj., Zatočnik pete sile, „Sveske” 2005, nr 78.

Polovina N., Kratka priča u stvaralačkom konceptu Zorana Živkovića, „Sveske” $2005, \mathrm{nr} 78$.

Živković Z., Biblioteka, Beograd 2008.

20 "osvetljavaju samo onaj kritični, granični segment vlastite egzistencije koji se odvija u času pripovedanja”, Lj. Pešikan-Ljuštanović, Zatočnik pete sile, „Sveske” 2005, nr 78, s. 55.

21 "otvara čitava nova, ogromna područja viših stvarnosti”, Beskrajno širenje književno kosmosa. Sa Zoranom Živkovićem razgovarala Tamara Jelin, „Sveske” 2005, nr 78, s. 76. 